\title{
Warming alters competition for organic and inorganic nitrogen between co-existing grassland plant species
}

\author{
Thomas M. Kuster • Anna Wilkinson • Paul W. Hill • \\ Davey L. Jones • Richard D. Bardgett
}

Received: 13 September 2015 / Accepted: 7 March 2016/Published online: 29 March 2016

(C) The Author(s) 2016. This article is published with open access at Springerlink.com

\begin{abstract}
Introduction Grass species may acquire different forms of nitrogen $(\mathrm{N})$ to reduce competition for the same resources. Climate change influences the availability of soil $\mathrm{N}$ and is therefore likely to cause shifts in $\mathrm{N}$ forms acquired by plants, thereby affecting their competitive interactions.

Methods We investigated the effects of warming on the uptake of different $\mathrm{N}$ forms and competitive interactions of Festuca ovina and Anthoxanthum odoratum in a pot experiment. The plants were grown either in monocultures or mixture, and at ambient or elevated temperature $\left(+10{ }^{\circ} \mathrm{C}\right)$, and supplied with ${ }^{13} \mathrm{C}$ and ${ }^{15} \mathrm{~N}$ isotopes to test for treatment effects on the relative uptake of ammonium, alanine or tri-alanine.

Results Both grass species took up relatively more $\mathrm{N}$ supplied as ammonium than as alanine or tri-alanine

Responsible Editor: Ad C. Borstlap.

Electronic supplementary material The online version of this article (doi:10.1007/s11104-016-2856-7) contains supplementary material, which is available to authorized users.
\end{abstract}

T. M. Kuster · A. Wilkinson · R. D. Bardgett

Faculty of Life Sciences, Michael Smith Building, The University of Manchester, Oxford Road, Manchester M13 9PT, UK

T. M. Kuster $(\bowtie)$

Institute for Plant Production Sciences, Agroscope, Schloss 1, 8820 Wädenswil, Switzerland

e-mail: thomaskuster@gmx.ch

P. W. Hill • D. L. Jones

School of Environment, Natural Resources and Geography, College of Natural Sciences, Bangor University, Gwynedd LL57 2UW, UK when grown under ambient conditions in monoculture. In contrast, when grown in mixtures, $F$. ovina took up the three supplied $\mathrm{N}$ forms in equal amounts, whereas A. odoratum switched to tri-alanine as the main $\mathrm{N}$ form. Under warmed conditions, both species took up the $\mathrm{N}$ forms equally, irrespective of competition treatments. Conclusions We have shown that grass species grown in mixture and under ambient conditions reduce competition by acquiring different $\mathrm{N}$ forms. Warming increased the availability of inorganic $\mathrm{N}$ in the soil and therefore deregulated the need for differential uptake of $\mathrm{N}$ forms.

Keywords Amino acid P Peptide - Nutrient . Coexistence $\cdot$ Niche differentiation

\section{Introduction}

Soil nitrogen $(\mathrm{N})$ availability is one of the most important growth-limiting factors in natural or semi-natural grasslands (Vitousek and Howarth 1991). There is growing evidence that increasing temperatures due to global warming will accelerate rates of soil $\mathrm{N}$ turnover in these and other temperature-limited ecosystems (Bai et al. 2013; IPCC 2013; Prescott 2010; Zhang et al. 2008), leading to increased soil $\mathrm{N}$ availability and a shift in the dominant $\mathrm{N}$ form from dissolved organic N (DON) to soluble inorganic N (DIN) (Bai et al. 2013; Rennenberg et al. 2009; Saxe et al. 2001). In addition to changing climate, changes in grassland land use, such as shifts in management intensity or grazing density, also modify microbial communities and rates of soil $\mathrm{N}$ turnover, causing shifts in the 
availability of different $\mathrm{N}$ forms (de Vries et al. 2012; Medina-Roldan et al. 2012), with the amount of DON relative to DIN being greater in low than in high productivity, intensively managed grasslands (Bardgett et al. 2003; Christou et al. 2005; Schimel and Bennett 2004).

It is well established that plant species are able to take up soil $\mathrm{N}$ in a range of forms, either as inorganic $\mathrm{N}$, in the form of ammonium $\left(\mathrm{NH}_{4}{ }^{+}\right)$and nitrate $\left(\mathrm{NO}_{3}{ }^{-}\right)$, or as organic $\mathrm{N}$, in the form of urea, amino acids and peptides (Näsholm et al. 2009; Näsholm and Persson 2001; Sauheitl et al. 2009b; Soper et al. 2011). Although grasses are relatively plastic with regard to their use of different $\mathrm{N}$ forms (Falkengren-Grerup et al. 2000; Sauheitl et al. 2009b), it has been suggested that under N limiting conditions grass species acquire contrasting forms of $\mathrm{N}$, which appear to be linked to their growth strategies (Kahmen et al. 2006; Weigelt et al. 2005). This plasticity in acquiring different $\mathrm{N}$ forms has been proposed to be a strategy for co-existing plant species to reduce niche overlap, and therefore to avoid competition for the same limiting resource (Ashton et al. 2010; McKane et al. 2002). Results from studies testing for niche partitioning based on chemical forms of $\mathrm{N}$ in grasslands, however, are mixed: some report differences in $\mathrm{N}$ forms taken up by co-existing grassland plant species (Ashton et al. 2010; Kahmen et al. 2006), whereas others do not (Ashton et al. 2008; Harrison et al. 2007).

Given that climatic conditions are known to regulate the availability of different $\mathrm{N}$ forms, it is likely that modified $\mathrm{N}$ availability due to warming will also lead to a shift in $\mathrm{N}$ forms taken up by plants. Indeed, Warren (2009) reported that Eucalyptus pauciflora Sieber ex Spreng. took up more glycine than nitrate at low temperatures, whereas the opposite was true when temperatures were higher due to changed $\mathrm{N}$ pool turnover rates. Similarly, in arctic tundra, glycine uptake by herbs was reduced by long-term warming (Sorensen et al. 2008), whereas glycine acquisition by the grass Deschampsia flexuosa (L.) was found to increase with warming (Andresen et al. 2009). Given this, our goal was to test how warming impacts the uptake of different $\mathrm{N}$ forms by grass species with contrasting life history strategies, and whether this influences their competitive interactions. We focused on two grass species that co-exist in low productivity, semi-natural temperate grassland: the slower-growing species Festuca ovina L. and the fastergrowing species Anthoxanthum odoratum L. (Elberse and Berendse 1993; Ryser and Wahl 2001; Schippers and Olff 2000; Schippers et al. 1999). These species have previously been shown to differ in their acquisition of organic and inorganic $\mathrm{N}$ forms in monoculture. Festuca rubra L., as a close relative to $F$. ovina, displays a selective placement in nutrient-rich patches with shorter roots and has been reported to take up relatively more inorganic than organic $\mathrm{N}$, whereas $A$. odoratum, with its longer roots spread more evenly in the soil, relies equally on both forms (Elberse and Berendse 1993; Harrison et al. 2007; Harrison et al. 2008; Mommer et al. 2011; Schippers and Olff 2000; Weigelt et al. 2005).

We hypothesised that: (i) the two grass species preferentially take up $\mathrm{N}$ supplied in different forms reflecting their differing life history strategies, and this difference is greater in mixture to avoid competition for soil $\mathrm{N}$; and (ii) at warmer temperatures preferences for $\mathrm{N}$ supplied in different forms become less important for F. ovina and A. odoratum due to increased availability of DIN compared to ambient temperatures. To test these hypotheses, we conducted a factorial pot experiment, in which $F$. ovina and A. odoratum were grown either in monocultures or mixtures at both ambient or elevated temperature, and were supplied with ${ }^{13} \mathrm{C}$ and ${ }^{15} \mathrm{~N}$ labelled compounds to test the relative uptake of ammonium (as a representative form of inorganic $\mathrm{N}$ ), alanine (amino acid) or tri-alanine (peptide).

\section{Materials and methods}

Experimental setup

We established a pot experiment using field soil collected from a grassland site at Abergwyngregyn, Gwynedd, North Wales, UK (53 $53^{\circ} 13$ ' 27" N, 4 $00^{\prime} 50^{\prime}$ W, $320 \mathrm{~m}$ a.s.1.), as described by Farrell et al. (2011a). Briefly, the selected site is classified as a semi-natural Agrostis-Festuca grassland, based on the UK National Vegetation Classification (Rodwell 1992), and is dominated by the grasses Agrostis canina L., Agrostis capillaris L., A. odoratum and F. ovina, and the herbs Potentilla erecta (L.) Raeusch. and Galium saxatile L. The soil is an organic matter rich Cambic Podzol with an acidic $\mathrm{pH}$ (4.8) and is representative of a typical seminatural, sheep-grazed upland grassland in the western United Kingdom (Bardgett et al. 2001). The dissolved N pool is rich in organic $\mathrm{N}\left(301 \pm 74 \mathrm{mg} \mathrm{m}^{-2}\right)$, whereas concentrations of $\mathrm{NH}_{4}^{+}-\mathrm{N}\left(73.4 \pm 36.8 \mathrm{mg} \mathrm{m}^{-2}\right)$ and $\mathrm{NO}_{3} \mathrm{~N}\left(0.6 \pm 0.5 \mathrm{mg} \mathrm{m}^{-2}\right)$ are lower (data refer to a 
depth of $15 \mathrm{~cm}$, published in Wilkinson et al. (2015)). The climate, measured at sea level at a distance of ca. $1 \mathrm{~km}$ from the sampling site, is cool and wet with a mean annual air temperature of $10.7^{\circ} \mathrm{C}$, soil temperature of $11{ }^{\circ} \mathrm{C}$ (at $10 \mathrm{~cm}$ depth) and rainfall of $1250 \mathrm{~mm}$. In spring 2013, soil from the field site was excavated from the rooting zone down to $15 \mathrm{~cm}$ depth. Soil was transported back to the laboratory where stones and roots were removed. After passing through a $4 \mathrm{~mm}$ sieve, the soil was thoroughly mixed and stored afterwards at $4{ }^{\circ} \mathrm{C}$ until the start of the experiment.

We selected two grass species: A. odoratum and $F$. ovina. Both species co-exist at the site, although $A$. odoratum is generally more abundant in more productive grasslands, and $F$. ovina is more abundant in lower productivity grasslands (Grime et al. 2007). In April 2013, seeds (Emorsgate Seeds, King's Lynn, UK) of $A$. odoratum and $F$. ovina were germinated in a $1: 1$ mixture $(v: v)$ of a low fertility compost (No 1; John Innes Manufacturers Association, Reading, UK) and horticulture sand (Keith Singleton Horticulture, Egremont, UK) at ambient temperatures in a greenhouse at The University of Manchester. Due to differences in germination and establishment rates, A. odoratum was sown 2 weeks later than $F$. ovina in order to produce uniformly sized seedlings. Trays were watered every second day with tap water without using any additional fertiliser. After 32 (A. odoratum) and 46 (F. ovina) days, seedlings with an average height of $9 \mathrm{~cm}$ were allocated to 3 intra- and interspecific planting treatments, each with two individual plants: i) $F$. ovina monoculture; ii) A. odoratum monoculture; and iii) F. ovina and A. odoratum mixture. Care was taken to ensure that the height of individuals in each of the 192 pots (side length $=9 \mathrm{~cm}$, used height $=7 \mathrm{~cm}$, average soil volume $=0.567 \mathrm{l}$ ) was similar. Immediately after planting, pots of each treatment were randomly assigned to two temperatures in controlled growth cabinets (day length $16 \mathrm{~h}$ ), namely: $12^{\circ} \mathrm{C}$, representing ambient growing season temperature, and $22{ }^{\circ} \mathrm{C}$, representing warming. The ambient temperature refers to an average temperature during growing seasons at the field site $\left(13.7{ }^{\circ} \mathrm{C}\right.$ at sea level, implying approximately $12{ }^{\circ} \mathrm{C}$ at the field site). Warming of $10{ }^{\circ} \mathrm{C}$ was used as an approach to extrapolate the climate sensitivity of $\mathrm{N}$ availability and uptake in a model ecosystem. Pots were randomly relocated within cabinets twice per week.

Pots were irrigated with tap water bi-weekly (ambient: $50 \mathrm{ml} \mathrm{pot}^{-1}$ week $^{-1}$; warming: $100 \mathrm{ml} \mathrm{pot}^{-1}$ week $^{-1}$, total dissolved $\mathrm{N}$ in tap water $<0.4 \mathrm{mg} \mathrm{l}^{-1}$ ), with differences in irrigation between the two treatments accounting for estimated greater evapotranspiration due to increased temperature and plant biomass in the warmed compared to ambient treatment. The difference in $\mathrm{N}$ input through irrigation between the treatments due to the different amount of water (ambient: $<0.16 \mathrm{mg} \mathrm{pot}^{-1}$; warming: $<0.32 \mathrm{mg} \mathrm{pot}^{-1}$ ) was negligible compared to total $\mathrm{N}$ per pot (approximately $2 \mathrm{~g} \mathrm{~N} \mathrm{pot}^{-1}$ ). The height of each seedling (longest shoot) was measured weekly.

Isotope labelling and harvest of plant biomass

Labelling of soils to measure uptake of different $\mathrm{N}$ forms was performed after 71 days, at a period when shoot height had remained stable for several weeks. Twelve replicate pots of each planting $\times$ temperature treatment were randomly allocated to the following three labelling treatments (72 out of 192 pots): i) ${ }^{15} \mathrm{NH}_{4} \mathrm{Cl}\left(98 \%{ }^{15} \mathrm{~N}\right.$, Cambridge Isotope Laboratories, Andover, MA, USA); ii) alanine $\left(97-99 \% \mathrm{U}_{-}{ }^{13} \mathrm{C}, 97-\right.$ $99 \%{ }^{15} \mathrm{~N}$, Cambridge Isotope Laboratories); and iii) trialanine, (97-99 \% U- ${ }^{13} \mathrm{C}, 97-99 \%{ }^{15} \mathrm{~N}, \mathrm{CK}$ Gas Products, Ibstock, UK). Nitrate concentration in the original field soil was negligible compared to DON and ammonium (Wilkinson et al. 2015), and therefore, nitrate was not used for labelling. There were 4 replicates for each treatment-labelling combination. The other 120 pots were treated with an unlabelled $\mathrm{N}$ solution $\left(18 \mu \mathrm{mol} \mathrm{N}\right.$ pot $\left.^{-1}\right)$, from which 8 pots were analysed for natural abundance assessments. Each labelling solution $\left(18 \mu \mathrm{mol} \mathrm{N} \mathrm{pot}{ }^{-1}\right)$ was made up of equal concentrations (6 $\mu \mathrm{mol} \mathrm{N}$ pot $^{-1}$ for each $\mathrm{N}$ form) of ammonium, alanine and tri-alanine, in which one of the three $\mathrm{N}$ forms was isotopically labelled. This enabled us to test for preferential uptake by individual plant species and soil microbes (Harrison et al. 2007; Weigelt et al. 2005). The use of dual-labelled ${ }^{13} \mathrm{C}^{15} \mathrm{~N}$ compounds is generally, but not unequivocally, considered to be a good indication whether amino acids and peptides such as alanine and tri-alanine are taken up by plants directly as organic $\mathrm{N}$, or as inorganic $\mathrm{N}$ after microbial mineralisation, as confirmed by enrichment of plant tissue with both ${ }^{13} \mathrm{C}$ and ${ }^{15} \mathrm{~N}$ (Näsholm et al. 1998). The amount of $\mathrm{N}$ added to each pot was considered to be sufficient to allow for detection of ${ }^{13} \mathrm{C}$ and ${ }^{15} \mathrm{~N}$ within plant and microbial biomass, but keeping the possible $\mathrm{N}$ fertilisation effect on plant growth to a minimum $\left(18 \mu \mathrm{mol} \mathrm{N}\right.$ pot $^{-1}$ $\left.\left(0.3 \mathrm{~kg} \mathrm{~N} \mathrm{ha}^{-1}\right)<\mathrm{N}_{\mathrm{H} 20}=490 \mu \mathrm{mol} \mathrm{N} \mathrm{pot}{ }^{-1}\right)$. Within 
each pot, the labelling solution $(20 \mathrm{ml})$ was injected at 5 different locations, equally distributed over the soil depth, using a glass syringe (S Murray \& Co, Surrey, UK). Pots were randomly labelled over a period of 4 days.

Three hours after labelling, pots were destructively harvested and plants were separated from the soil. A chase period of $3 \mathrm{~h}$ was chosen to reduce plant uptake of recycled mineralised organic $\mathrm{N}$, but to provide sufficient time to detect ${ }^{13} \mathrm{C}^{15} \mathrm{~N}$ in roots and shoots (Warren 2012). Roots were first washed with deionised water and then rinsed with $0.5 \mathrm{M} \mathrm{CaCl}_{2}$ to remove ${ }^{13} \mathrm{C}$ and ${ }^{15} \mathrm{~N}$ in the apoplast and sorbed to the cell wall. Roots of the two species in the mixed treatment were distinguished from each other by their colour. Root, shoot and soil samples were dried at $65{ }^{\circ} \mathrm{C}$ for 2 days prior to grinding (MM 400, Retsch, Haan, Germany). Root and shoot samples of the two individuals grown in monocultures were pooled prior to grinding, whereas for mixed treatments both individuals were analysed separately.

Root and, shoot extract samples were analysed for ${ }^{12 / 13} \mathrm{C}$ and ${ }^{14 / 15} \mathrm{~N}$ concentrations at the NERC Life Sciences Mass Spectrometer Facility, Centre for Ecology and Hydrology, Lancaster, UK, (precision for working standards better than $0.46 \%$ o $\left({ }^{13} \mathrm{C}\right)$ and $6.92 \%$ $\left.\left({ }^{15} \mathrm{~N}\right)\right)$. Samples were combusted in a Carlo Erba NA1500 elemental analyser (Thermo Scientific, Waltham, MA, USA). The resultant $\mathrm{CO}_{2} / \mathrm{N}_{2}$ from combustion and reduction was analysed for $\delta^{13} \mathrm{C} /{ }^{15} \mathrm{~N}$ using an isotope ratio mass spectrometer (IRMS; Dennis Leigh Technologies, Sandbach, UK). ${ }^{13} \mathrm{C}^{15} \mathrm{~N}$ excess values were calculated by using formulas (1) and (2).

$\mathrm{R}_{\text {sample }}=\left[\left(\delta^{13} \mathrm{C} / 1000\right)+1\right] * \mathrm{R}_{\mathrm{PDB}}$

where $\mathrm{R}$ is the ratio of ${ }^{13} \mathrm{C} /$ of ${ }^{15} \mathrm{~N}$ to ${ }^{12} \mathrm{C} /$ to ${ }^{14} \mathrm{~N}$ and $\mathrm{R}_{\mathrm{PDB}}$ is the natural abundance standard for $\mathrm{C}$ and $\mathrm{N}$.

Atom $\%=(\mathrm{R} / \mathrm{R}+1) * 100$

Atom $\%$ excess values were calculated by subtracting control atom $\%$ values from treatment atom $\%$ values. Natural abundance levels of ${ }^{13} \mathrm{C}$ in our samples were highly variable. We therefore used the lowest natural abundance atom $\%$ value to calculate ${ }^{13} \mathrm{C}$ excess values.

Soil nutrients, microbial biomass and root length

Immediately after plants were harvested, fresh soil samples were extracted with deionised water $(1: 7.1 \mathrm{w} / \mathrm{v}$ soil:extractant; extraction time $=10 \mathrm{~min}$ ) to measure total dissolved $\mathrm{N}$ and inorganic $\mathrm{N}$ as either nitrate $\left(\mathrm{NO}_{3}{ }^{-}\right)$or ammonium $\left(\mathrm{NH}_{4}{ }^{+}\right)$. Extracts were measured with an AutoAnalyzer 3 (SEAL Analytical, Fareham, UK). DON was calculated after subtracting watersoluble inorganic $\mathrm{N}$ from total water-soluble $\mathrm{N}$. Dissolved organic carbon (DOC) was measured in water extracts using a TOC-L analyser (Shimadzu, Kyoto, Japan). For determining microbial $\mathrm{C}\left(\mathrm{C}_{\text {mic }}\right)$ and $\mathrm{N}$ $\left(\mathrm{N}_{\text {mic }}\right)$, chloroform-fumigated (fumigation time $=24 \mathrm{~h}$, amylene-stabilised $\mathrm{CHCl}_{3}$, Fisher Scientific, Waltham, MA, USA) and non-fumigated soil samples were extracted with $0.5 \mathrm{M} \mathrm{K}_{2} \mathrm{SO}_{4}(1: 2.5 \mathrm{w} / v$ soil:extractant; extraction time $=60 \mathrm{~min}$ ) (Brookes et al. 1985), and total soluble organic carbon and $\mathrm{N}$ in $\mathrm{K}_{2} \mathrm{SO}_{4}$-extracts were measured with a TOC-L (Shimadzu, Kyoto, Japan) and an AutoAnalyzer 3 (SEAL Analytical, Fareham, UK), respectively. Microbial biomass was calculated as the respective differences between fumigated and non-fumigated samples. The differences were divided by the corrections factors $k_{\mathrm{EC}}=0.35$ and $k_{\mathrm{EN}}=0.50$ to estimate $\mathrm{C}_{\text {mic }}$ and $\mathrm{N}_{\text {mic }}$ (Carter 2008). In labelled soil samples, $\mathrm{pH}$ was measured in $0.01 \mathrm{M} \mathrm{CaCl}_{2}$ (FE20, Mettler-Toledo, Schwerzenbach, Switzerland). Root samples from pots that were not used for the labelling experiment were analysed for their diameter and length using an Epson Expression 11,000 XL, scanner (Nagano, Japan) and WinRHIZO Pro 2013a (Regent Instruments Inc., Quebec, CA).

Statistical analysis

Data were analysed after log-transformation by ANOVA using a linear model (significant at $P<0.05$ ) in R 3.02 (R Development Core Team, Vienna, AT). The initial shoot height (analysis of root and shoot biomass) and final biomass $\left({ }^{12 / 13} \mathrm{C}^{14 / 15} \mathrm{~N}\right.$ values) were included in the models to account for differences between pots. Selected differences between treatments and soils were pair-wise tested using contrasts based on $t$-tests (significant at $P<0.05$ ).

\section{Results}

Soil $\mathrm{N}$ availability and microbial biomass

Concentrations of inorganic $\mathrm{N}\left(\mathrm{NH}_{4}{ }^{+}\right.$and $\left.\mathrm{NO}_{3}{ }^{-}\right)$were influenced by planting and warming treatments (Table 1). Concentrations of $\mathrm{NH}_{4}{ }^{+}\left(F_{(2,181)}=36.6\right.$, 
Table 1 Soil properties at the end of the experiment

\begin{tabular}{|c|c|c|c|c|c|c|c|c|c|}
\hline & \multicolumn{3}{|l|}{ Ambient } & \multicolumn{3}{|l|}{ Warming } & \multicolumn{3}{|l|}{$F$-values } \\
\hline & $\begin{array}{l}\text { F. ovina } \\
\text { monoculture }\end{array}$ & $\begin{array}{l}\text { A. odoratum } \\
\text { monoculture }\end{array}$ & Mixture & $\begin{array}{l}\text { F. ovina } \\
\text { monoculture }\end{array}$ & $\begin{array}{l}\text { A. odoratum } \\
\text { monoculture }\end{array}$ & Mixture & $\mathrm{T}$ & $\mathrm{P}$ & $\mathrm{T} \times \mathrm{P}$ \\
\hline SWC & $* 41.1 \pm 1.0^{\mathrm{a}}$ & $39.2 \pm 1.2^{\mathrm{a}}$ & $38.0 \pm 1.0^{\mathrm{a}}$ & $* 45.0 \pm 1.6^{\mathrm{a}}$ & $31.2 \pm 1.7^{\mathrm{b}}$ & $34.0 \pm 2.1^{\mathrm{b}}$ & $9.6^{* *}$ & $17.6^{* * *}$ & $8.3 * * *$ \\
\hline $\mathrm{C}_{\text {tot }}$ & $90.1 \pm 1.6^{\mathrm{a}}$ & $91.8 \pm 0.7^{\mathrm{a}}$ & $92.5 \pm 0.8^{\mathrm{a}}$ & $91.4 \pm 0.6^{\mathrm{a}}$ & $91.2 \pm 1.0^{\mathrm{a}}$ & $92.2 \pm 1.9^{\mathrm{a}}$ & $<0.1$ & 0.9 & 0.4 \\
\hline DOC & $62.1 \pm 5.7^{\mathrm{a}}$ & $73.3 \pm 4.8^{\mathrm{a}}$ & $63.4 \pm 5.1^{\mathrm{a}}$ & $56.4 \pm 4.8^{\mathrm{a}}$ & $65.3 \pm 2.9^{\mathrm{b}}$ & $59.2 \pm 4.3^{\mathrm{ab}}$ & 1.5 & $4.7^{*}$ & 0.1 \\
\hline $\mathrm{N}_{\text {tot }}$ & $7.8 \pm 0.1^{\mathrm{a}}$ & $7.8 \pm 0.0^{\mathrm{a}}$ & $7.9 \pm 0.0^{\mathrm{a}}$ & $7.9 \pm 0.1^{\mathrm{a}}$ & $7.8 \pm 0.1^{\mathrm{a}}$ & $7.9 \pm 0.1^{\mathrm{a}}$ & $<0.1$ & 0.8 & 0.5 \\
\hline $\mathrm{NH}_{4}^{+}$ & $* 2.7 \pm 0.7^{\mathrm{a}}$ & $* 1.3 \pm 0.1^{\mathrm{b}}$ & $* 1.6 \pm 0.2^{\mathrm{a}}$ & $* 10.9 \pm 1.7^{\mathrm{a}}$ & $* 2.3 \pm 0.3^{\mathrm{b}}$ & $* 3.5 \pm 0.5^{\mathrm{b}}$ & $88.0 * * *$ & $36.6^{* * *}$ & $8.7 * * *$ \\
\hline $\mathrm{NO}_{3}^{-}$ & $* 12.0 \pm 2.0^{\mathrm{a}}$ & $* 2.5 \pm 0.5^{\mathrm{b}}$ & $* 7.2 \pm 1.6^{\mathrm{a}}$ & $* 57.9 \pm 4.4^{\mathrm{a}}$ & $* 6.5 \pm 1.2^{\mathrm{b}}$ & $* 14.9 \pm 2.9^{\mathrm{c}}$ & $59.9 * * *$ & $44.9 * * *$ & $7.7 * * *$ \\
\hline DON & $3.9 \pm 0.3^{\mathrm{a}}$ & $* 5.5 \pm 1.0^{\mathrm{a}}$ & $4.0 \pm 0.3^{\mathrm{a}}$ & $2.9 \pm 0.6^{\mathrm{a}}$ & $* 3.5 \pm 0.3^{\mathrm{a}}$ & $4.1 \pm 0.2^{\mathrm{a}}$ & $5.2 *$ & 2.2 & 2.1 \\
\hline $\mathrm{Mic}_{\mathrm{C}}$ & $* 1.9 \pm 0.1^{\mathrm{a}}$ & $* 1.9 \pm 0.1^{\mathrm{a}}$ & $1.6 \pm 0.1^{\mathrm{b}}$ & $* 1.2 \pm 0.1^{\mathrm{a}}$ & $* 1.4 \pm 0.1^{\mathrm{b}}$ & $1.7 \pm 0.1^{\mathrm{b}}$ & $26.6^{* * *}$ & 2.1 & $11.8^{* * *}$ \\
\hline $\mathrm{Mic}_{\mathrm{N}}$ & $* 0.29 \pm 0.01^{\mathrm{a}}$ & $* 0.30 \pm 0.02^{\mathrm{a}}$ & $0.28 \pm 0.01^{\mathrm{a}}$ & $* 0.23 \pm 0.01^{\mathrm{a}}$ & $* 0.25 \pm 0.01^{\mathrm{ab}}$ & $0.26 \pm 0.01^{\mathrm{b}}$ & $18.5^{* * *}$ & 0.7 & $2.9^{(*)}$ \\
\hline
\end{tabular}

Values are mean \pm SE. An asterisk * indicates a significant difference between warming treatments within the same competition treatment (all $P<0.05$ ). Different letters indicate significant differences between competition treatments within the same warming treatment. SWC: soil water concentration $(\%, n=32$, residual $d f=183), \mathrm{C}_{\text {tot }}$ : total carbon $\left(\mathrm{mg} \mathrm{g}^{-1}, 8,42\right)$, DOC: dissolved organic C $\left(\mu \mathrm{g} \mathrm{g}{ }^{-1}, 32,186\right), \mathrm{N}_{\text {tot }}$ : total nitrogen $\left(\mathrm{mg} \mathrm{g}^{-1}, 12,66\right), \mathrm{NH}_{4}^{+}$: ammonium $\left(\mu \mathrm{g} \mathrm{g}^{-1}, 32,181\right), \mathrm{NO}_{3}^{-}$: nitrate $\left(\mu \mathrm{g} \mathrm{g}^{-1}, 32,181\right)$, DON: dissolved organic nitrogen $\left(\mu \mathrm{g} \mathrm{g}^{-1}, 32,181\right), \mathrm{Mic}_{\mathrm{C}}$ : microbial carbon $\left(\mathrm{mg} \mathrm{g}^{-1}, 32,167\right), \mathrm{Mic}_{\mathrm{N}}$ : microbial nitrogen $\left(\mathrm{mg} \mathrm{g}^{-1}, 32,167\right)$. Statistical analyses $(F-$ values): Effects of temperature $(\mathrm{T}, d f=1)$, planting $(\mathrm{P}, d f=2)$ and their interactions $(\mathrm{T} \times \mathrm{P}, d f=2)$, levels of significances $(* * *: P<0.001, * *: P<0.01$, *: $P<0.05,(*): P<0.1))$

$P<0.001)$ and $\mathrm{NO}_{3}{ }^{-}\left(F_{(2,181)}=44.9, P<0.001\right)$ were lowest in soil planted with $A$. odoratum, followed by mixtures and $F$. ovina monocultures. Soil concentrations of $\mathrm{NH}_{4}{ }^{+}\left(F_{(1,181)}=88.0, P<0.001\right)$ and $\mathrm{NO}_{3}{ }^{-}$ $\left(F_{(1,181)}=59.9, P<0.001\right)$ were greater in the warming than in the ambient treatment. Dissolved organic $\mathrm{N}$ (DON) was lower in the ambient treatment than the warming treatment $\left(F_{(1,181)}=5.2, P=0.023\right)$. Pairwise comparisons for DON were, however, only significant in A. odoratum monocultures $(P=0.007)$ and not in the other planting treatments $(F$. ovina monocultures: $P=0.171$; mixtures: $P=0.895)$. Dissolved organic carbon (DOC) was changed by the planting treatment $\left(F_{(2,186)}=4.7, P=0.010\right)$ : DOC concentrations were, or tended to be greater in $A$. odoratum than in $F$. ovina monocultures (ambient: $P=0.054$; warming: $P=0.028)$. There was, however, no warming effect on soil DOC, and neither total soil carbon $\left(\mathrm{C}_{\mathrm{tot}}\right)$, nitrogen $\left(\mathrm{N}_{\text {tot }}\right)$ or $\mathrm{pH}$ were affected by the warming and planting treatments (Table 1). Soil water concentration at the end of the experiment was greatest in warmed $F$. ovina monoculture, whereas no differences between the other treatments were observed.

Both microbial biomass $\mathrm{C}\left(F_{(1,167)}=26.6, P<0.001\right)$ and $\mathrm{N}\left(F_{(1,167)}=4.1, P=0.045\right)$ were greater in the ambient than in the warming treatment (Table 1).
However, effects of warming on microbial biomass $\mathrm{C}$ (temperature $\times$ planting: $\left.F_{(2,167)}=11.8, P<0.001\right)$ and $\mathrm{N}$ (temperature $\times$ planting: $F_{(1,167)}=5.5, P=0.005$ ) varied with planting design: under ambient conditions, microbial biomass $\mathrm{C}$ was lowest in mixtures, whereas under warmed conditions it was smallest in $F$. ovina monocultures. Similarly, microbial biomass N under warming was lower in $F$. ovina monocultures than in mixtures, but not different from $A$. odoratum monocultures. We observed no differences in microbial $\mathrm{N}$ between the planting treatments under ambient conditions.

\section{Root and shoot biomass}

Elevated temperature on average doubled the shoot biomass of $A$. odoratum, whereas warming only marginally influenced shoot biomass of $F$. ovina (temperature $\times$ species: $F_{(1,247)}=91.9, P<0.001$, Fig. 1a). The planting treatment only affected shoot biomass of $A$. odoratum in the warming treatment (temperature $\times$ planting: $\left.F_{(1,247)}=4.5, P=0.035\right)$ : A. odoratum shoot biomass per plant was $50 \%$ higher in mixtures than in monocultures (competition ratio $(\mathrm{CR})=1.5 \pm 0.1$ ). However, total shoot biomass per pot (2 plants) in warmed A. odoratum monocultures did not differ from the total biomass of the two species in mixtures 


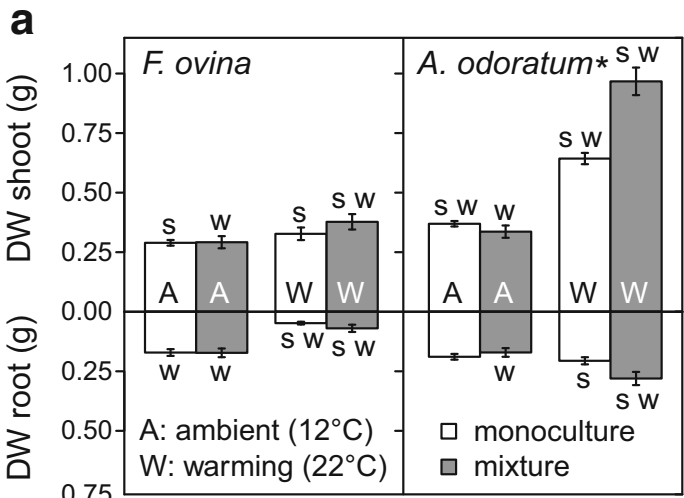

Fig. 1 a Average root and shoot biomass per individual $(\mathrm{g}, \pm \mathrm{SE}$, $n=32$ ), separately shown for each temperature and planting treatment. Total root length is shown in Fig. S1. b Average nitrogen $(\mathrm{N})$ concentrations in root and shoot biomass $(\%, \pm \mathrm{SE}$, $n=12$ ). Please note that the $\mathrm{y}$-axis (shoot $\mathrm{N}$ ) starts at $2 \%$. a \& b Values of the two individuals in the monoculture treatment were

$(P=0.745)$. Planting treatment had no effect on the shoot biomass of $A$. odoratum under ambient temperature $(\mathrm{CR}=0.9 \pm 0.1)$, or on shoot biomass of $F$. ovina under ambient $(\mathrm{CR}=1.0 \pm 0.1)$ or warmed conditions $(\mathrm{CR}=1.2 \pm 0.1)$.

Warming decreased root biomass of $F$. ovina in monoculture and mixtures, but it had no effect on root biomass of $A$. odoratum in monoculture, although it increased root biomass of this species in mixtures (temperature $\times$ species: $F_{(1,247)}=49.7, P<0.001$, Fig. 1a). As a result, under elevated temperatures, root biomass of A. odoratum was more than four times greater than of F. ovina, whereas root biomass did not differ between the two species under ambient conditions (Fig. 1a). Warming decreased the root:shoot ratio of the test spe$\operatorname{cies}\left(F_{(1,247)}=178.9, P<0.001\right)$ : the effect of temperature on the root:shoot ratio of $F$. ovina was greater than on that of $A$. odoratum (temperature $\times$ species: $\left.F_{(1,247)}=39.8, P<0.001\right)$, leading to a significantly higher root:shoot ratio of $A$. odoratum than of $F$. ovina in the warming treatment. There was no significant planting effect on root biomass or root:shoot ratio of either species $\left(F_{(1,247)}=1.6, P=0.201, F_{(1,247)}=0.8\right.$, $P=0.383$ ). As with root biomass, root length of $F$. ovina was least in the warming than in the ambient treatment, whereas root length of $A$. odoratum grown in mixtures was greater under warming than ambient conditions (temperature $\times$ planting: $F_{(1,143)}=55.4, P<0.001$, Fig. S1A). No warming effect on root length was observed in A. odoratum monocultures; hence, root length

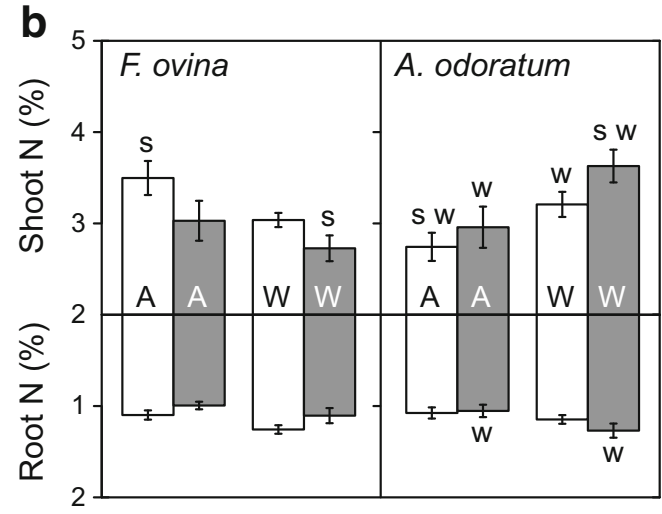

pooled prior analysis. Significant $(P<0.05)$ pair-wise comparisons are indicated by $*$ : difference between monoculture and mixed treatments within the same species and temperature treatment; s: difference between species within the same temperature and competition treatment; w: difference between temperature treatments within the same species and competition treatment

of $A$. odoratum was greater than of $F$. ovina, but only under warmed conditions.

$\mathrm{N}$ concentrations in root and shoot

Temperature effects on shoot $\mathrm{N}$ differed between the two grass species (temperature $\times$ species: $F_{(1,87)}=37.1$, $P<0.001)$ : shoot $\mathrm{N}$ in $A$. odoratum was greater under warming than under ambient temperature, whereas for F. ovina no effect of warming was detected (Fig. 1b). Planting design also influenced the two species differently (planting x species: $F_{(1,87)}=19.4, P<0.001$ ). Although pair-wise comparisons were not significant, shoot $\mathrm{N}$ in $A$. odoratum tended to be greater in mixtures than in monocultures, whereas it was the other way around in $F$. ovina. Hence, shoot $\mathrm{N}$ concentrations under ambient and monoculture conditions were higher in F. ovina than in A. odoratum $(P=0.004)$, whereas $\mathrm{N}$ concentrations were lower in $F$. ovina than in A. odoratum in warmed mixture $(P=0.001)$. In general, root $\mathrm{N}$ concentrations were greater under elevated than under ambient temperature $\left(F_{(1,87)}=9,1, P<0.001\right.$, Fig. 1b). However, pair-wise comparisons revealed that this response to warming was only significant in $A$. odoratum roots grown in mixtures $(P=0.015)$.

${ }^{13} \mathrm{C}^{15} \mathrm{~N}$ excess values in root and shoot biomass

Enrichment of plant material, measured as absolute ${ }^{15} \mathrm{~N}$ excess values, differed strongly between the two grass 
species (roots: $F_{(1,71)}=21.1, P<0.001$; shoots: $\left.F_{(1,71)}=72.9, P<0.001\right)$. On average, ${ }^{15} \mathrm{~N}$ excess values in roots and shoots of $A$. odoratum were higher than in those of $F$. ovina, which is indicative of greater uptake of all $\mathrm{N}$ forms (Fig. 2). Differences in ${ }^{13} \mathrm{C}$ excess values between the two species, however, were only weakly or not significant (roots: $F_{(1,47)}=3.6, P=0.064$; shoots: $\left.F_{(1,71)}=5.8, P=0.020\right)$, although there was a trend towards higher ${ }^{13} \mathrm{C}$ concentrations in A. odoratum than F. ovina (Table 3).

Plant uptake of $\mathrm{N}$ was affected by chemical $\mathrm{N}$ form (roots: $F_{(2,71)}=18.1, P<0.001$; shoots: $F_{(2,71)}=22.2$, $P<0.001$ ), planting design (roots: $F_{(1,71)}=10.0$, $P=0.002$; shoots: $\left.F_{(1,71)}=22.0, P<0.001\right)$ and warming treatment (roots: $F_{(2,71)}=6.5, P=0.013$; shoots: $\left.F_{(2,71)}=57.1, P<0.001\right)$. Most interestingly, planting treatment influenced the uptake of $\mathrm{N}$ forms by A. odoratum under ambient conditions: in monoculture, ${ }^{15} \mathrm{~N}$ excess rates in $A$. odoratum roots and shoots were greater for ammonium than alanine (roots; shoots: $P<0.001 ; P<0.001)$ or tri-alanine $(P=0.066$; $P=0.023)$, whereas in mixture uptake of $\mathrm{N}$ supplied as tri-alanine was greater than as ammonium $(P=0.049$; $P=0.860)$ or alanine $(P=0.011 ; P=0.005)$. This shift in $\mathrm{N}$ forms taken up by $A$. odoratum can mainly be deduced from a smaller ammonium uptake in mixture than in monoculture $(P<0.001 ; P=0.016)$, whereas we observed no difference in uptake of $\mathrm{N}$ supplied as trialanine between the planting treatments. In $F$. ovina roots and shoots grown at ambient conditions, differences between $\mathrm{N}$ forms were less obvious than for A. odoratum. In monoculture, uptake of $\mathrm{N}$ supplied as alanine was less than for ammonium $(P<0.001$; $P<0.001)$ and tri-alanine $(P=0.020 ; P=0.083)$. In mixture, we observed no difference in uptake of different $\mathrm{N}$ forms on the basis of ${ }^{15} \mathrm{~N}$ excess in $F$. ovina roots, but values in shoots were greater when plants were labelled with ammonium than with alanine $(P=0.001)$ or tri-alanine $(P=0.032)$. Recovery rates in roots of the applied ammonium and alanine were the same for the two species in mixture, whereas more tri-alanine was found in roots of $A$. odoratum than in roots of $F$. ovina $(P=0.012$, Table 2$)$. No differences in recovery rates in roots between the two species were found when they were grown in monocultures. Both in monocultures and mixtures, all labelling solutions were found to a higher extent in A. odoratum shoots than in F. ovina shoots. Over all, the conclusions gained from comparing the relative numbers presented as recovery rates are, however, the same as found when using excess values. Root uptake of ${ }^{13} \mathrm{C}$ was also affected by the chemical form $\left(F_{(1,47)}=16.5, P<0.001\right)$; under ambient conditions ${ }^{13} \mathrm{C}$
Fig. 2 Average ${ }^{15} \mathrm{~N}$ excess rates in root (a) and shoot biomass (b) after a chasing period of $3 \mathrm{~h}$ $\left(\mu \mathrm{mol} \mathrm{g}{ }^{-1}, \pm \mathrm{SE}, n=4\right)$, separately shown for $\mathrm{NH}_{4}{ }^{+}$, alanine and tri-alanine.

Differences between the applied tracer solutions within a given treatment combination (column) are indicated by different letters (all $P<0.05$ ). Average ${ }^{13} \mathrm{C}$ excess values are shown in Table 3. Please note the different scales between the two species

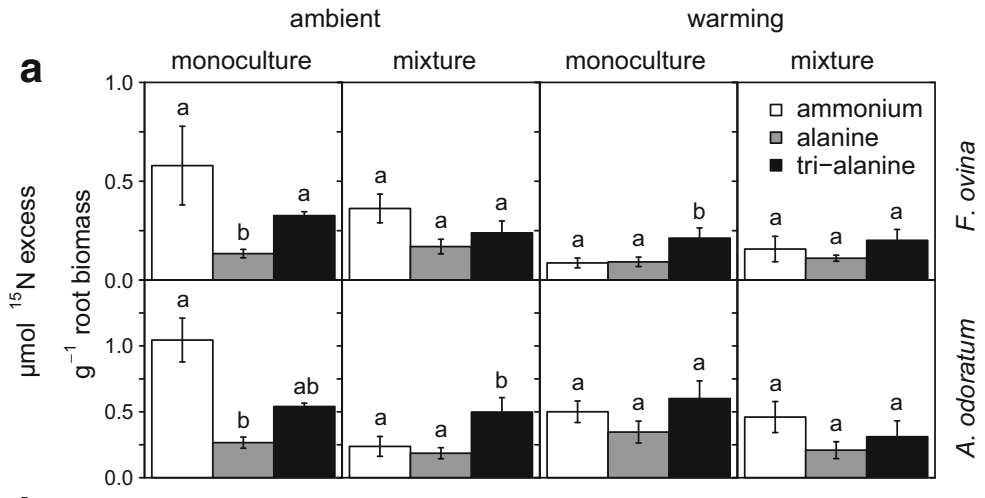

b

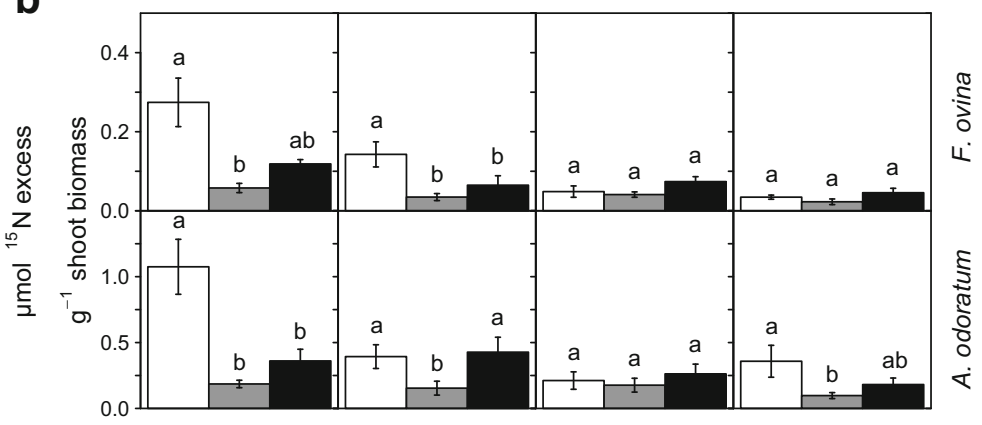


Table 2 Average recovery rates of the applied labelling solutions in roots and shoots after a chasing period of $3 \mathrm{~h}(\%, \mathrm{SE}, n=4)$, separately shown for ammonium, alanine and tri-alanine

\begin{tabular}{|c|c|c|c|c|c|c|}
\hline & \multicolumn{3}{|l|}{ F. ovina } & \multicolumn{3}{|l|}{ A. odoratum } \\
\hline & Ammonium & Alanine & Tri-alanine & Ammonium & Alanine & Tri-alanine \\
\hline \multicolumn{7}{|l|}{ Roots } \\
\hline Ambient monoculture & $2.3 \pm 1.0^{\mathrm{a}}$ & $0.6 \pm 0.1^{\mathrm{b}}$ & $1.1 \pm 0.2^{\mathrm{ab}}$ & $3.9 \pm 0.8^{\mathrm{a}}$ & $1.1 \pm 0.2^{\mathrm{b}}$ & $2.1 \pm 0.5^{\mathrm{ab}}$ \\
\hline Ambient mixture & $1.5 \pm 0.2^{\mathrm{a}}$ & $0.9 \pm 0.3^{\mathrm{a}}$ & $* 0.8 \pm 0.4^{\mathrm{a}}$ & $0.8 \pm 0.4^{\mathrm{a}}$ & $0.6 \pm 0.1^{\mathrm{a}}$ & $* 2.8 \pm 0.6^{\mathrm{b}}$ \\
\hline Warming monoculture & $* 0.1 \pm 0.0^{\mathrm{a}}$ & $* 0.1 \pm 0.0^{\mathrm{a}}$ & $* 0.4 \pm 0.1^{\mathrm{b}}$ & $* 1.9 \pm 0.5^{\mathrm{a}}$ & $* 1.9 \pm 0.5^{\mathrm{a}}$ & $* 1.9 \pm 0.1^{\mathrm{a}}$ \\
\hline Warming mixture & $* 0.2 \pm 0.1^{\mathrm{a}}$ & $* 0.3 \pm 0.2^{\mathrm{a}}$ & $* 0.3 \pm 0.1^{\mathrm{a}}$ & $* 3.4 \pm 1.1^{\mathrm{a}}$ & $* 1.2 \pm 0.5^{\mathrm{b}}$ & $* 2.1 \pm 1.2^{\mathrm{ab}}$ \\
\hline \multicolumn{7}{|l|}{ Shoots } \\
\hline Ambient monoculture & $* 1.4 \pm 0.5^{\mathrm{a}}$ & $* 0.3 \pm 0.0^{\mathrm{b}}$ & $* 0.4 \pm 0.1^{\mathrm{ab}}$ & $* 6.2 \pm 1.5^{\mathrm{a}}$ & $* 1.1 \pm 0.1^{\mathrm{b}}$ & $* 2.1 \pm 0.6^{\mathrm{b}}$ \\
\hline Ambient mixture & $* 0.6 \pm 0.1^{\mathrm{a}}$ & $* 0.2 \pm 0.1^{\mathrm{b}}$ & $* 0.3 \pm 0.1^{\mathrm{ab}}$ & $* 1.9 \pm 0.6^{\mathrm{a}}$ & $* 0.8 \pm 0.3^{\mathrm{b}}$ & $* 2.4 \pm 0.6^{\mathrm{a}}$ \\
\hline Warming monoculture & $* 0.2 \pm 0.0^{\mathrm{ab}}$ & $* 0.2 \pm 0.1^{\mathrm{a}}$ & $* 0.5 \pm 0.1^{\mathrm{b}}$ & $* 2.2 \pm .8^{\mathrm{a}}$ & $* 1.8 \pm 0.5^{\mathrm{a}}$ & $* 2.1 \pm 0.3^{\mathrm{a}}$ \\
\hline Warming mixture & $* 0.2 \pm 0.0^{\mathrm{ab}}$ & $* 0.1 \pm 0.0^{\mathrm{a}}$ & $* 0.2 \pm 0.0^{\mathrm{b}}$ & $* 5.9 \pm 2.0^{\mathrm{a}}$ & $* 1.5 \pm 0.3^{\mathrm{a}}$ & $* 2.6 \pm 1.0^{\mathrm{a}}$ \\
\hline
\end{tabular}
indicates a significant difference between species within the same labelling solution and competition treatment (all $P<0.05)$

excess values were higher when plants were labelled with tri-alanine than with alanine (Table 3).

Warming changed the observed planting effects on ${ }^{15} \mathrm{~N}$ uptake under ambient conditions (temperature $\times$ form in roots: $F_{(2,71)}=3.0, P=0.056$; shoots: $\left.F_{(2,71)}=6.6, P=0.002\right)$; in general, we detected no differences in ${ }^{15} \mathrm{~N}$ and ${ }^{13} \mathrm{C}$ excess values in both species between the applied $\mathrm{N}$ forms under warmed conditions (Fig. 2, Table 3). As an exception to this pattern, ${ }^{15} \mathrm{~N}$ excess values for $F$. ovina roots in monoculture were greater for tri-alanine than ammonium $(P=0.033)$ or alanine $(P=0.023)$, and for $A$. odoratum shoots, ${ }^{15} \mathrm{~N}$ excess values were greater for ammonium than alanine $(P=0.033)$. Due to the differences in biomass (Fig. 1), higher recovery rates of the applied labelling solutions were found under elevated temperatures in roots and shoots of $A$. odoratum compared to $F$. ovina (Table 2).

We found significant correlations between ${ }^{13} \mathrm{C}$ and ${ }^{15} \mathrm{~N}$ excess values in $A$. odoratum roots for alanine $\left(R^{2}=0.287, P=0.027\right)$ and tri-alanine $\left(R^{2}=0.401\right.$, $P=0.011$, Fig. 3). The slope of the alanine correlation line $(\mathrm{m}=0.9)$ was slightly steeper than that of tri-alanine $(\mathrm{m}=0.5)$. We estimate that about a third to a sixth of alanine and tri-alanine were taken up directly, respectively. This indicates that direct uptake of alanine was greater than for tri-alanine, that the proportion ${ }^{13} \mathrm{C}$ lost in plant respiration was greater when acquired as trialanine than when acquired as alanine, or that the $\mathrm{C}$

Table 3 Mean ${ }^{13} \mathrm{C}$ excess values $\left(\mathrm{nmol}^{13} \mathrm{C}\right.$ excess $\mathrm{g}^{-1}$ ) in roots and shoots, separately shown for the ${ }^{13} \mathrm{C}$ labelling solutions alanine and trialanine. Values are mean $\pm \mathrm{SE}, n=4$

\begin{tabular}{|c|c|c|c|c|c|c|c|c|}
\hline & \multicolumn{4}{|l|}{ Ambient } & \multicolumn{4}{|l|}{ Warming } \\
\hline & $\begin{array}{l}\text { F. ovina } \\
\text { monoculture }\end{array}$ & $\begin{array}{l}\text { A. odoratum } \\
\text { monoculture }\end{array}$ & $\begin{array}{l}F \text {. ovina } \\
\text { mixture }\end{array}$ & $\begin{array}{l}\text { A. odoratum } \\
\text { mixture }\end{array}$ & $\begin{array}{l}\text { F. ovina } \\
\text { monoculture }\end{array}$ & $\begin{array}{l}\text { A. odoratum } \\
\text { monoculture }\end{array}$ & $\begin{array}{l}F . \text { ovina } \\
\text { mixture }\end{array}$ & $\begin{array}{l}\text { A. odoratum } \\
\text { mixture }\end{array}$ \\
\hline \multicolumn{9}{|l|}{ Roots } \\
\hline Alanine & $279 \pm 49^{\mathrm{a}}$ & $* 235 \pm 60^{\mathrm{a}}$ & $* 129 \pm 39^{\mathrm{b}}$ & $259 \pm 50^{\mathrm{a}}$ & $439 \pm 49^{\mathrm{a}}$ & $558 \pm 113^{\mathrm{a}}$ & $348 \pm 91^{\mathrm{a}}$ & $440 \pm 109^{\mathrm{a}}$ \\
\hline Tri-alanine & $474 \pm 35^{\mathrm{a}}$ & $* 475 \pm 23^{\mathrm{a}}$ & $* 268 \pm 64^{\mathrm{a}}$ & $487 \pm 67^{\mathrm{a}}$ & $567 \pm 46^{\mathrm{a}}$ & $702 \pm 83^{\mathrm{a}}$ & $397 \pm 71^{\mathrm{a}}$ & $585 \pm 103^{\mathrm{a}}$ \\
\hline \multicolumn{9}{|l|}{ Shoots } \\
\hline Alanine & $190 \pm 82^{\mathrm{a}}$ & $269 \pm 47^{\mathrm{a}}$ & $55 \pm 111^{\mathrm{a}}$ & $310 \pm 168^{\mathrm{a}}$ & $298 \pm 41^{\mathrm{a}}$ & $428 \pm 74^{\mathrm{a}}$ & $221 \pm 149^{\mathrm{a}}$ & $324 \pm 78^{\mathrm{a}}$ \\
\hline Tri-alanine & $168 \pm 50^{\mathrm{a}}$ & $292 \pm 75^{\mathrm{a}}$ & $189 \pm 134^{\mathrm{a}}$ & $212 \pm 59^{\mathrm{a}}$ & $347 \pm 46^{\mathrm{a}}$ & $475 \pm 63^{\mathrm{a}}$ & $235 \pm 58^{\mathrm{a}}$ & $347 \pm 84^{\mathrm{a}}$ \\
\hline
\end{tabular}

Different letters indicate significant differences between species and competition treatments within the same warming treatment and $\mathrm{N}$ form (all $P<0.05$ ). An asterisk * indicates a significant difference between $\mathrm{N}$ forms within a given treatment 


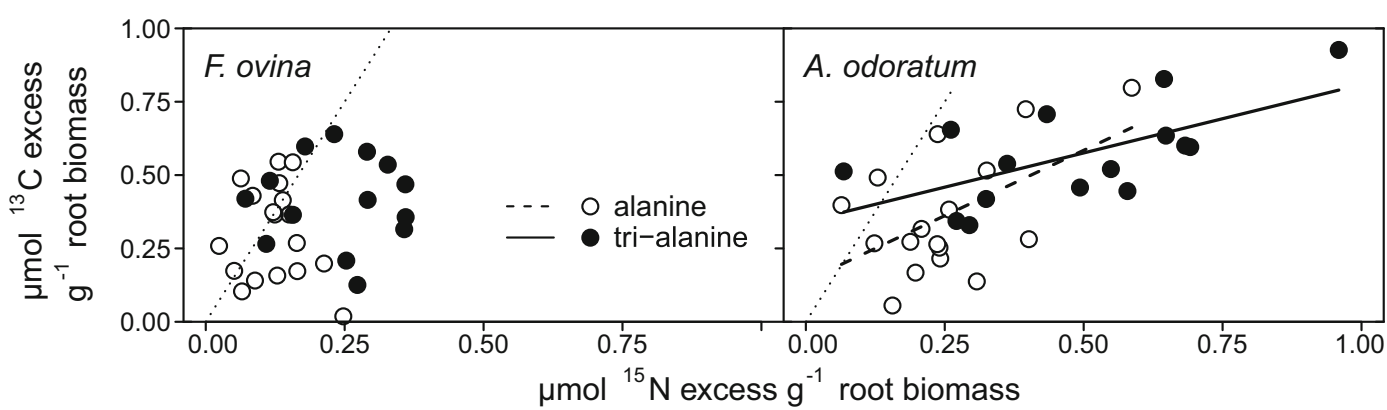

Fig. 3 Relationship between ${ }^{13} \mathrm{C}$ and ${ }^{15} \mathrm{~N}$ excess values in roots of A. odoratum and F. ovina, separately shown for alanine (open circles) and tri-alanine (closed circles). Broken (alanine: $R^{2}=0.287, P=0.027$ ) and solid lines (tri-alanine: $R^{2}=0.401$, $P=0.011$ ) show significant regressions between the excess of both

and $\mathrm{N}$ from the compounds partitioned differently between roots and shoots. But given that these relationships are only weakly significant, these numbers needs to be interpreted with care. In F. ovina roots, we observed no correlations between ${ }^{13} \mathrm{C}$ and ${ }^{15} \mathrm{~N}$ excess values (alanine: $R^{2}=0.022, P=0.557$; tri-alanine: $\left.R^{2}<0.001, P=0.946\right)$. The slopes of the correlation lines separately calculated for each planting and warming treatment did not differ from the patterns described above.

\section{Discussion}

The aim of this study was to test for the effects of warming on the uptake of different $\mathrm{N}$ forms and competitive interactions of two grass species of temperate grasslands with contrasting functional traits. Our first hypothesis was that the two grass species take up different forms when grown in monocultures, and this difference is greater in mixture to avoid competition for soil $\mathrm{N}$. In contrast to this hypothesis, and to previous studies on inorganic and organic N uptake (Harrison et al. 2007; Harrison et al. 2008; Weigelt et al. 2005), we found that both $F$. ovina and $A$. odoratum took up more $\mathrm{N}$ supplied as ammonium than as alanine when grown in monocultures. When grown in mixture, however, A. odoratum, but not $F$. ovina, switched from taking up more $\mathrm{N}$ from ammonium than alanine, to greater uptake of $\mathrm{N}$ supplied as tri-alanine than as alanine or ammonium. The difference in $\mathrm{N}$ uptake between these species in mixture is reflected in their functional root traits: Festuca is known to place roots selectively in nutrient-rich hotspots, whereas Anthoxanthum spreads its roots more evenly isotopes in A. odoratum roots. The regressions in $F$. ovina roots were not significant (alanine: $R^{2}=0.022, P=0.557$; tri-alanine: $R^{2}<0.001, P=0.946$ ). The dotted lines show the molar ${ }^{13} \mathrm{C}:{ }^{15} \mathrm{~N}$ ratios for the nitrogen sources injected $(3: 1)$

in soil, allowing uptake of a greater variety of $\mathrm{N}$ forms (Mommer et al. 2011). This suggests that when grown in mixture, $F$. ovina was more competitive than $A$. odoratum in taking up the same $\mathrm{N}$ form as in monoculture, thereby reducing $A$. odoratum's ammonium uptake. Competition for $\mathrm{N}$ between plants and microbes was presumably strong in both monocultures and mixtures and, therefore, A. odoratum could not compensate the reduced ammonium uptake by acquiring more $\mathrm{N}$ supplied as alanine or tri-alanine. Moreover, we exclude that competition between microbes and plants explains the decreased ammonium uptake by $A$. odoratum as this would likewise have affected ammonium uptake by F. ovina. Our data, therefore, suggest that this shift in $\mathrm{N}$ uptake by $A$. odoratum was mainly induced by a lower competitiveness for ammonium in comparison with $F$. ovina, which lends support to the idea that acquisition of different $\mathrm{N}$ forms contributes to coexistence of competing grass species (Ashton et al. 2010; Kahmen et al. 2006; McKane et al. 2002).

As hypothesised, we found that warming changed $\mathrm{N}$ use by the two plant species, in that we detected no difference in uptake of the different $\mathrm{N}$ forms when they were grown in mixture compared to monocultures in this treatment. It is possible that increased soil inorganic $\mathrm{N}$ availability under warming compensated for the need for niche differentiation on the basis of $\mathrm{N}$ form, which was detected in mixtures under ambient conditions. Indeed, nitrate and ammonium concentrations were greater in the warming than ambient treatment, which is likely to be due to accelerated organic matter turnover in this organic-rich grassland soil (Bai et al. 2013; Prescott 2010; Rennenberg et al. 2009; Zhang et al. 2008). An alternative mechanism is that warming 
influenced the competitiveness of the two grass species, which might have weakened in the requirement for niche differentiation; whereas under ambient conditions the biomass of the two species was similar, A. odoratum clearly outcompeted $F$. ovina in the warming treatment. In a study conducted by Schippers and Olff (2000), A. odoratum was still more vigorous than $F$. ovina at $15{ }^{\circ} \mathrm{C}$, indicating that the optimum temperature of F. ovina is rather closer to $12{ }^{\circ} \mathrm{C}$ than to $22^{\circ} \mathrm{C}$. The lower root:shoot ratio and plant $\mathrm{N}$ concentrations of $F$. ovina compared to A. odoratum indicate that the differences in competiveness between our test species can be related to a more effective nutrient uptake by $A$. odoratum compared to $F$. ovina in the warmed treatment (Mommer et al. 2011). Otherwise, the low root biomass of $F$. ovina under warming might have been a consequence of the high soil water availability in the F. ovina monoculture relative to A. odoratum and mixtures. This would mean that due to sufficient water availability in the topsoil there was no need for $F$. ovina to allocate resources to root growth and hence $F$. ovina was likely less competitive in taking up nutrients compared to A. odoratum. With its higher root density, A. odoratum is likely to be also more competitive under water-limiting conditions, as predicted to increase in frequency with climate change (IPCC 2013); this question, however, was not tested in our experiment and needs further investigation. It is possible that, in the long term, niche partitioning on the basis of uptake of different forms of $\mathrm{N}$ will occur in the real world under warming, especially due to acclimatisation of microbial activity and increased plant biomass production ( $\mathrm{Lu}$ et al. 2013; Luo et al. 2001) or immigration of other species (Klanderud and Birks 2003; Parolo and Rossi 2008). We therefore conclude, in accordance with our second hypothesis, that warming reduces the need for niche differentiation on the basis of $\mathrm{N}$ form in grass species, at least in the short timescale of our study.

Even though our data show how competition and temperature influence the uptake of $\mathrm{N}$ forms by $F$. ovina and $A$. odoratum, the applied ${ }^{13} \mathrm{C}^{15} \mathrm{~N}$ labelling technique has some limitations. First, it is possible that $\mathrm{N}$ forms other than those we supplied to soil might have also been important for plant nutrition. Unlike in the field (Wilkinson et al. 2015), concentrations of nitrate were higher than ammonium or DON in soil of the present experiment. We found that soil nitrate concentrations were reduced under ambient conditions by the presence of $A$. odoratum, indicating that nitrate was a significant part of nutrition for A. odoratum. Soil concentrations of nitrate in mixtures, however, suggest that A. odoratum did not increase its nitrate acquisition when grown alongside with $F$. ovina. Hence, even though A. odoratum may have taken up a significant amount of nitrate, our conclusions, gained from the reduced ammonium uptake in mixture compared to monoculture, would not be different. Second, correlations between ${ }^{13} \mathrm{C}$ and ${ }^{15} \mathrm{~N}$ excess values in $A$. odoratum roots and ${ }^{13} \mathrm{C}^{15} \mathrm{~N}$ excess values in microbes may indicate that a higher fraction of tri-alanine, compared to alanine, was first mineralised then taken up as inorganic N, as similarly reported by Farrell et al. (2013). We presume, however, that direct uptake of tri-alanine was nevertheless an important source for plant nutrition: on the one hand we found higher plant ${ }^{13} \mathrm{C}$ excess values for trialanine than for alanine, indicating that direct uptake of the peptide was, in absolute numbers, higher than of the monomer; on the other hand, differences between ${ }^{13} \mathrm{C}$ and ${ }^{15} \mathrm{~N}$ correlations might be explained by faster within-plant mineralisation of tri-alanine compared to alanine (Hill et al. 2011; Warren 2012). In other words, residual carbon, including ${ }^{13} \mathrm{C}$, might have been respired to a higher extent when applied as peptide than as amino acid, resulting in a smaller ${ }^{13} \mathrm{C}^{15} \mathrm{~N}$ ratio. To reduce such uncertainties about direct uptake of labelled isotopes in future experiments, the application of other techniques might be helpful, such as compound-specific stable isotope measurements (Sauheitl et al. 2009a), positionspecific labeling (Apostel et al. 2013) and the use of ${ }^{14} \mathrm{C}$-labelled isotopes (Hill et al. 2013). However, all available techniques are subject to some caveats and assumptions. Third, pool dilution of applied labelling solutions has to be taken into account when interpreting ${ }^{13} \mathrm{C}$ and ${ }^{15} \mathrm{~N}$ uptake in plant samples (Jones et al. 2005). We neither have any data on alanine or tri-alanine concentrations in our pots nor do we know the specificity of the transporters in the roots. However at the location where we collected field soil, concentrations of alanine, tri-alanine and other amino acids and peptides competing for the same root transporters were smaller than those of ammonium (Farrell et al. 2011a; Farrell et al. 2011b). Hence, the chance of a plant root to take up labelled ammonium was smaller in comparison with labelled $\mathrm{N}$ supplied in organic forms. Otherwise, considering the faster turnover rates of amino acids and peptides comparing to ammonium, plants have much more capacity to take up ${ }^{15} \mathrm{~N}_{-} \mathrm{NH}_{4}{ }^{+}$during the labelling period. Taking pool dilution into account by multiplying 
soil N pools in the field reported by Farrell et al. (2011b) by ${ }^{15} \mathrm{~N}$ excess values recorded within root or shoot tissue in the present experiment, we estimate that 30$100 \times$ more ${ }^{15} \mathrm{~N}^{-\mathrm{NH}_{4}}$ was recovered in plant material than the tested organic ${ }^{15} \mathrm{~N}$ forms. Likely, differences in $\mathrm{N}$ uptake in ambient monocultures would be even more distinct when considering pool dilution, whereas shifts in $\mathrm{N}$ uptake by $A$. odoratum grown in mixture would be less obvious. However, as this correction would likewise apply for both monocultures and mixture, the relative difference in ammonium uptake would not be different and hence, our main conclusions from this experiment are still likely to be true. We recognize that these data do not necessarily reflect the $\mathrm{N}$ pools in our experiment, but they provide and approximation of the likely level of dilution commonly found in the field.

\section{Conclusions}

Our data show that grass species grown in mixture and under ambient conditions reduce competition by taking up different $\mathrm{N}$ forms. Thereby, $\mathrm{N}$ supplied in organic forms as amino acids and peptides can play a major role for plant nutrition. Hence, the possibilities for a plant species to create its own niche are manifold and may include intricacies such as acquiring different $\mathrm{N}$ forms. Increased availability of inorganic $\mathrm{N}$ due to warming deregulated the need for differential uptake of $\mathrm{N}$ forms. Hence, we conclude that uptake of different $\mathrm{N}$ forms is mainly important at nutrient-limiting conditions. Besides taking up different $\mathrm{N}$ forms, grass species have also been shown to coexist through spatiotemporal shifts in nutrient acquisition (McKane et al. 1990; Pornon et al. 2007). Whereas we exclude spatiotemporal shifts in $\mathrm{N}$ uptake as a source for niche differentiation in the present study, these other strategies might explain why in some field studies niche differentiation by taking up different $\mathrm{N}$ forms has been reported (Ashton et al. 2010; Kahmen et al. 2006), whereas in others it has not (Ashton et al. 2008; Harrison et al. 2007).

Acknowledgments We thank Helen Grant and Andy Stott from the NERC Life Sciences Mass Spectrometer Facility, Centre for Ecology and Hydrology, Lancaster, UK for conducting the stable isotope measurements. For funding these measurements, we acknowledge the National Environment Research Council NERC (Proposal no. CEH_L_069_05_2013). We thank Corina Del Fabbro, Deborah Ashworth, Hayley Craig, David Grantham, Richard Preziosi and Simon Turner for their help in performing the experiment. We acknowledge Corina Del Fabbro for her support in data analysis. Financial support was provided by the Swiss National Science Foundation SNSF (Proposal no. 145973) and BBSRC (Grant Reference BB/I009000/2).

Open Access This article is distributed under the terms of the Creative Commons Attribution 4.0 International License (http:// creativecommons.org/licenses/by/4.0/), which permits unrestricted use, distribution, and reproduction in any medium, provided you give appropriate credit to the original author(s) and the source, provide a link to the Creative Commons license, and indicate if changes were made.

\section{References}

Andresen LC, Michelsen A, Jonasson S, Beier C, Ambus P (2009) Glycine uptake in heath plants and soil microbes responds to elevated temperature, $\mathrm{CO}_{2}$ and drought. Acta Oecol 35:786-796

Apostel C, Dippold M, Glaser B, Kuzyakov Y (2013) Biochemical pathways of amino acids in soil: assessment by position-specific labeling and 13 C-PLFA analysis. Soil Biol Biochem 67:31-40

Ashton IW, Miller AE, Bowman WD, Suding KN (2008) Nitrogen preferences and plant-soil feedbacks as influenced by neighbors in the alpine tundra. Oecologia 156:625-636

Ashton IW, Miller AE, Bowman WD, Suding KN (2010) Niche complementarity due to plasticity in resource use: plant partitioning of chemical N forms. Ecology 91:3252-3260

Bai E, Li S, Xu W, Li W, Dai W, Jiang P (2013) A meta-analysis of experimental warming effects on terrestrial nitrogen pools and dynamics. New Phytol 199:441-451

Bardgett RD, Jones AC, Jones DL, Kemmitt SJ, Cook R, Hobbs PJ (2001) Soil microbial community patterns related to the history and intensity of grazing in sub-montane ecosystems. Soil Biol Biochem 33:1653-1664

Bardgett RD, Streeter TC, Bol R (2003) Soil microbes compete effectively with plants for organic-nitrogen inputs to temperate grasslands. Ecology 84:1277-1287

Brookes PC, Landman A, Pruden G, Jenkinson D (1985) Chloroform fumigation and the release of soil nitrogen: a rapid direct extraction method to measure microbial biomass nitrogen in soil. Soil Biol Biochem 17:837-842

Carter MR (2008) Soil sampling and methods of analysis. CRC Press, Boca Raton

Christou M, Avramides EJ, Roberts JP, Jones DL (2005) Dissolved organic nitrogen in contrasting agricultural ecosystems. Soil Biol Biochem 37:1560-1563

de Vries FT, Bloem J, Quirk H, Stevens CJ, Bol R, Bardgett RD (2012) Extensive management promotes plant and microbial nitrogen retention in temperate grassland. PLoS One 7

Elberse WT, Berendse F (1993) A comparative study of the growth and morphology of eight grass species from habitats with different butrient availabilities. Funct Ecol 7:223-229

Falkengren-Grerup U, Mansson KF, Olsson MO (2000) Uptake capacity of amino acids by ten grasses and forbs in relation to soil acidity and nitrogen availability. Environ Exp Bot 44: 207-219 
Farrell M, Hill PW, Farrar J, Bardgett RD, Jones DL (2011a) Seasonal variation in soluble soil carbon and nitrogen across a grassland productivity gradient. Soil Biol Biochem 43:835844

Farrell M, Hill PW, Wanniarachchi SD, Farrar J, Bardgett RD, Jones DL (2011b) Rapid peptide metabolism: A major component of soil nitrogen cycling? Glob Biogeochem Cycles 25

Farrell M, Hill PW, Farrar J, DeLuca TH, Roberts P, Kielland K, Dahlgren R, Murphy DV, Hobbs PJ, Bardgett RD, Jones DL (2013) Oligopeptides represent a preferred source of organic N uptake: a global phenomenon? Ecosystems 16:133-145

Grime JP, Hodgson JG, Hunt R (2007) Comparative plant ecology a functional approach to common British species. Castlepoint Press, Dalbeattie

Harrison KA, Bol R, Bardgett RD (2007) Preferences for different nitrogen forms by coexisting plant species and soil microbes. Ecology 88:989-999

Harrison KA, Bol R, Bardgett RD (2008) Do plant species with different growth strategies vary in their ability to compete with soil microbes for chemical forms of nitrogen? Soil Biol Biochem 40:228-237

Hill PW, Quilliam RS, DeLuca TH, Farrar J, Farrell M, Roberts P, Newsham KK, Hopkins DW, Bardgett RD, Jones DL (2011) Acquisition and assimilation of nitrogen as peptide-bound and D-enantiomers of amino acids by wheat. PLoS One 6

Hill PW, Marsden KA, Jones DL (2013) How significant to plant $\mathrm{N}$ nutrition is the direct consumption of soil microbes by roots? New Phytol 199:948-955

IPCC (2013) Climate change 2013: the physical science basis. contribution of Working Group I to the fifth assessment report of the intergovernmental panel on climate change. Cambridge University Press, Cambridge

Jones DL, Healey JR, Willett VB, Farrar JF, Hodge A (2005) Dissolved organic nitrogen uptake by plants - an important N uptake pathway? Soil Biol Biochem 37:413-423

Kahmen A, Renker C, Unsicker SB, Buchmann N (2006) Niche complementarity for nitrogen: An explanation for the biodiversity and ecosystem functioning relationship? Ecology 87 : 1244-1255

Klanderud K, Birks HJB (2003) Recent increases in species richness and shifts in altitudinal distributions of Norwegian mountain plants. The Holocene 13:1-6

Lu M, Zhou X, Yang Q, Li H, Luo Y, Fang C, Chen J, Yang X, Li B (2013) Responses of ecosystem carbon cycle to experimental warming: a meta-analysis. Ecology 94:726-738

Luo Y, Wan S, Hui D, Wallace LL (2001) Acclimatization of soil respiration to warming in a tall grass prairie. Nature 413:622625

McKane RB, Grigal DF, Russelle MP (1990) Spatiotemporal differences in N-15 uptake and the organization of an oldfield plant community. Ecology 71:1126-1132

McKane RB, Johnson LC, Shaver GR, Nadelhoffer KJ, Rastetter EB, Fry B, Giblin AE, Kielland K, Kwiatkowski BL, Laundre JA, Murray G (2002) Resource-based niches provide a basis for plant species diversity and dominance in arctic tundra. Nature 415:68-71

Medina-Roldan E, Paz-Ferreiro J, Bardgett RD (2012) Grazing exclusion affects soil and plant communities, but has no impact on soil carbon storage in an upland grassland. Agric Ecosyst Environ 149:118-123
Mommer L, Visser EJW, van Ruijven J, de Caluwe H, Pierik R, de Kroon H (2011) Contrasting root behaviour in two grass species: a test of functionality in dynamic heterogeneous conditions. Plant Soil 344:347-360

Näsholm T, Persson J (2001) Plant acquisition of organic nitrogen in boreal forests. Physiol Plant 111:419-426

Näsholm T, Ekblad A, Nordin A, Giesler R, Högberg M, Högberg $\mathrm{P}(1998)$ Boreal forest plants take up organic nitrogen. Nature 392:914-916

Näsholm T, Kielland K, Ganeteg U (2009) Uptake of organic nitrogen by plants. New Phytol 182:31-48

Parolo G, Rossi G (2008) Upward migration of vascular plants following a climate warming trend in the Alps. Basic Appl Ecol 9:100-107

Pornon A, Escaravage N, Lamaze T (2007) Complementarity in mineral nitrogen use among dominant plant species in a subalpine community. Am J Bot 94:1778-1785

Prescott CE (2010) Litter decomposition: what controls it and how can we alter it to sequester more carbon in forest soils? Biogeochemistry 101:133-149

Rennenberg H, Dannenmann M, Gessler A, Kreuzwieser J, Simon J, Papen H (2009) Nitrogen balance in forest soils: nutritional limitation of plants under climate change stresses. Plant Biol 11:4-23

Rodwell JS (1992) British plant communities. Volume 3. Grassland and montane communities. Cambridge University Press, Cambridge

Ryser R, Wahl S (2001) Interspecific variation in RGR and the underlying traits among 24 grass species grown in full daylight. Plant Biol 3:426-436

Sauheitl L, Glaser B, Weigelt A (2009a) Advantages of compound-specific stable isotope measurements over bulk measurements in studies on plant uptake of intact amino acids. Rapid Commun Mass Spectrom 23:3333-3342

Sauheitl L, Glaser B, Weigelt A (2009b) Uptake of intact amino acids by plants depends on soil amino acid concentrations. Environ Exp Bot 66:145-152

Saxe H, Cannell MGR, Johnsen B, Ryan MG, Vourlitis G (2001) Tree and forest functioning in response to global warming. New Phytol 149:369-399

Schimel JP, Bennett J (2004) Nitrogen mineralization: challenges of a changing paradigm. Ecology 85:591-602

Schippers P, Olff H (2000) Biomass partitioning, architecture and turnover of six herbaceous species from habitats with different nutrient supply. Plant Ecol 149:219-231

Schippers P, Snoeijing I, Kropff MJ (1999) Competition under high and low nutrient levels among three grassland species occupying different positions in a successional sequence. New Phytol 143:547-559

Soper FM, Paungfoo-Lonhienne C, Brackin R, Rentsch D, Schmidt S, Robinson N (2011) Arabidopsis and Lobelia anceps access small peptides as a nitrogen source for growth. Funct Plant Biol 38:788-796

Sorensen PL, Michelsen A, Jonasson S (2008) Nitrogen uptake during one year in subarctic pant functional groups and in microbes after long-term warming and fertilization. Ecosystems 11:1223-1233

Vitousek PM, Howarth RW (1991) Nitrogen limitation on land and in the sea: how can it occur? Biogeochemistry $13: 87-115$ 
Warren CR (2009) Why does temperature affect relative uptake rates of nitrate, ammonium and glycine: A test with Eucalyptus pauciflora. Soil Biol Biochem 41:778-784

Warren CR (2012) Post-uptake metabolism affects quantification of amino acid uptake. New Phytol 193:522-531

Weigelt A, Bol R, Bardgett RD (2005) Preferential uptake of soil nitrogen forms by grassland plant species. Oecologia 142: 627-635
Wilkinson A, Hill PW, Vaieretti MV, Farrar JF, Jones DL, Bardgett RD (2015) Challenging the paradigm of nitrogen cycling: no evidence of in situ resource partitioning by coexisting plant species in grasslands of contrasting fertility. Ecol Evol 5:275-287

Zhang DQ, Hui DF, Luo YQ, Zhou GY (2008) Rates of litter decomposition in terrestrial ecosystems: global patterns and controlling factors. J Plant Ecol 1:85-93 